\section{Trochus and Pearl-Shell in Queensland Waters}

IN vol. 4, pt. 1 of the Report of the Great Barrier Reef Committee (Brisbane: Government Printer), Mr. F. W. Moorhouse deals with products of economic importance-green turtle, Trochus and sponges. His work on the life-history of the turtle is referred to elsewhere in this issue (p. 715). As regards Trochus, there is little fresh work reported, but the question of size limits is discussed, $2 \frac{1}{2}$ in. in greatest basal diameter being regarded as essential. Shirt buttons having red, brown or greenish markings on their under sides are made from Trochus shell. The shell and button industry for the last few years has been more or less out of commission all over the world, owing to the dictates of fashion and the economic depression, so that probably the matter of size restriction is not urgent. Would it not be well for Queensland to consider the development of the farming of the much more valuable pearl-shell in its waters? A single farm in full operation might quite well produce 1,000 tons a year, which is more than the average catch of the last ten years in all Queensland waters. Such a farm might as a side-line develop the planting out and growth of sponges as Moorhouse has shown.

\section{The Sky in November}

THIS month is marked by the appearance of two notable meteor showers, the Leonids and the Andromedids. The Leonids appear from November 9 until November 20, the greatest display being on November 14 and 15. The radiant is at 10 hours R.A. and $+23^{\circ}$ declination, so that the meteors will only be visible immediately before sunrise. The Andromedids appear from November 20 until November 30, the greatest display being from November 20 until November 23. The radiant is at $1 \mathrm{~h} .40 \mathrm{~min}$. R.A. and $+43^{\circ}$ declination. As the sun's right ascension is about fifteen hours at this time of year, the display is well placed in the eastern evening sky. Venus reaches its maximum eastern elongation on November 25. It will be very bright-its magnitude will be $-4 \cdot 1$ and the planet will be about $23^{\circ}$ above the horizon at sunset. Mars will set about two hours after the sun in the middle of November.

\section{Announcements}

IT is announced that His Majesty the King, accompanied by the Queen, hopes to open the New Medical School of St. Mary's Hospital, Paddington, London, on December 12.

THe Medical Research Council has appointed Prof. E. P. Cathcart, of the University of Glasgow, to be chairman of the Industrial Health Research Board in succession to Sir Arnold Wilson, who has resigned on becoming a member of Parliament. Prof. Cyril Burt and Miss Hilda Martindale have been appointed members of the Board in succession to Sir John Parsons and Miss M. Ritson, who have retired in rotation.
Achema VII, the well-known German exhibition of chemical apparatus and plant, will be held in Cologne on May 18-27, 1934, simultaneously with that of the German Chemical Trades Association ('Dechema'), and with important conferences of leading trades associations and technical societies. Information can be obtained from 'Achema', Management Offices, Seelze, near Hannover.

British Drug Houses, Ltd, have issued the third edition of the pamphlet " $\mathrm{P}_{\mathrm{H}}$ Values" and also a new catalogue of indicators, accessories and outfits for the determination of hydrogen ion concentration. The former is very practical and informative, and the catalogue is very comprehensive. Copies may be obtained from the firm, Graham Street, N.1.

A CATALOGUE of miscellaneous books, including a selected list of works on Africa, America, Egypt, India, China and Japan, issued by Messrs. W. Dawson and Son of Cannon House, Pilgrim Street, London, E.C., includes an item of considerable interest to students of the early history of aeronautics. This is a collection of prints, formed by a French collector, relating to the early years of aeronautics, that is, about 1780. Of the eighty items in the collection, about 36 are hand-coloured or partly hand-coloured.

Messrs. Sir Isaac Pitman and Sons, Litd., have just issued the first part of a second edition of their "Building Educator" (price 1s. 3d, net). The whole work will be completed in thirty fortnightly parts. It will deal with all aspects of building and should be especially valuable to apprentices, students and claftsmen. It will cover practically all examination work, and at the end a copious index will be provided. A list of the subjects to be dealt with is given in this first number, together with the names of some forty contributors, among whom are Profs. F. C. Lea, H. Adams, C. H. Reilly, and Sir Banister Fletcher, who deals with craftsmanship in building. It is essentially a work which should be in the readingroom of technical schools and colleges.

Applications are invited for the following appointments, on or before the dates mentioned :-An analytical chemist in the Medical Department of the Gold Coast-Director of Recruitment, Colonial Office, 2, Richmond Terrace, Whitehall, S.W.1 (Nov, 15). A University reader in botany at Birkbeck CollegeThe Academic Registrar, University of London, S.W.7 (Nov. 17). An assistant (physics) in the Admiralty Technical Pool-The Secretary of the Admiralty, C.E. Branch (Nov. 18). An assistant lecturer in agriculture and farm book-keeping at the Cheshire School of Agriculture, Reaseheath, Nantwich - The Principal (Nov. 22). A lecturer in chemistry at Rhodes University College, Grahamstown, South Africa-The High Commissioner for the Union of South Africa, Trafalgar Square, London, W.C.2 (Nov. 30). An assistant lecturer in agriculture at the Midland Agricultural College, Sutton Bonington, Loughborough--The Prineipal. 